\title{
Avaliação da qualidade da água em poços de abastecimento de hotéis de Ipojuca/PE
}

A concentração de grandes centros urbanos ao longo da costa brasileira, e o crescente interesse por áreas próximas as praias para moradia ou lazer, tem levado ao aumento na demanda de abastecimento de água, principalmente nas cidades turísticas. Para suprir a necessidade de consumo do distrito de Porto de Galinhas, no município de Ipojuca em Pernambuco, tem sido adotada a explotação de águas subterrâneas como alternativa para suprir esse déficit. Neste contexto, este trabalho objetivou caracterizar o padrão de potabilidade de águas captadas de poços tubulares que abastecem hotéis no município de Ipojuca e apresentar medidas que contribuam para melhorar a qualidade das águas dos poços estudados. A investigação foi conduzida por meio de um levantamento de dados secundários obtidos da Agência Pernambucana de Águas e Climas (APAC) e Agência Estadual de Meio Ambiente (CPRH), no período entre 2010 e 2018, em que foram avaliados parâmetros microbiológico e físico-químico conforme Portaria de Consolidação № 5 de 2017 do Ministério da Saúde. Foi utilizado o software Qualigraf para a realização do balanço iônico e construção do diagrama de Piper para a classificação das águas coletadas. Os resultados indicam que há uma predominância de águas do tipo cloretada sódica. As águas em geral são apropriadas ao consumo humano, satisfazendo na maioria dos casos, os critérios de potabilidade definidos pelas leis ambientais vigentes. Algumas razões iônicas obtidas no presente estudo não se encontram nas faixas de variação características das águas continentais indicando a possibilidade de intrusão salina.

Palavras-chave: Águas Subterrâneas; Aquífero Costeiro; Qualidade de Água; Gestão Hídrica; Salinização.

\section{Evaluation of water quality in wells that supply hotels in Ipojuca/PE}

The concentration of large urban centers along the Brazilian coast, and the growing interest in areas close to the beaches for housing or leisure, has led to the increase in demand for water supply, mainly in tourist cities. To meet the need for consumption of the district of Porto de Galinhas, in the municipality of Ipojuca in Pernambuco, it has been adopted the explotation of groundwater as an alternative to supply this deficit. In this context, this study aimed to characterize the potability pattern of water collected from tubular wells supplying hotels in the municipality of Ipojuca and to present measures that contribute to improve the quality of the wells studied. An investigation was conducted using secondary data from reports obtained from the Agência Pernambucana de Águas e Climas (APAC) and Agência Estadual de Meio Ambiente (CPRH), in the period between 2010 and 2018, where microbiological and physicochemical parameters of the water samples were evaluated for the quality of waters destined to human consumption, according to the Consolidation Ordinance № 5 of 2017 of the Ministry of Health. The Qualigraf software was used to perform the ionic balance and the construction of Piper diagram used to classify the collected waters. The results indicate the predominance of sodium chloride waters. The water in general is appropriate for human consumption, where, in most cases, the potability criteria defined by the current environmental laws are satisfied. Some ionic reasons obtained in the present study are not found in the ranges of variation characteristic of the continental waters indicating the possibility of saline intrusion.

Keywords: Groundwater; Coastal Aquifers; Water Quality; Hydric Management; Salinization.

Topic: Uso de Recursos Naturais

Reviewed anonymously in the process of blind peer.
Received: 01/11/2019

Approved: $18 / 02 / 2020$
Ricardo Fonseca Rodrigues de Figueiredo Instituto de Tecnologia de Pernambuco, Brasil http://lattes.cnpq.br/5273203712329653 rfrfpe@gmail.com

\section{Sonia Valeria Pereira (id}

Universidade Católica de Pernambuco, Brasil

http://lattes.cnpq.br/1460143644333839

http://orcid.org/0000-0001-8676-2943

soniaitep@gmail.com

\section{Referencing this:}

FIGUEIREDO, R. F. R.; PEREIRA, S. V.. Avaliação da qualidade da água em poços de abastecimento de hotéis de Ipojuca/PE. Natural Resources, v.10, n.1, p.17-26, 2020. DOI: http://doi.org/10.6008/CBPC2237-9290.2020.001.0003 


\section{INTRODUÇÃO}

Eleita pela décima vez consecutiva a praia mais bonita do Brasil, Porto de Galinhas é o maior polo turístico do estado de Pernambuco. A sua cadeia produtiva gera em torno de 20.000 empregos diretos e indiretos na cadeia do turismo. As praias do município possuem 167 meios de hospedagem, entre pousadas, hotéis, hotéis de lazer e flats, com capacidade de 13.500 leitos.

Considerando a deficiência no abastecimento de água potável para a população de Pernambuco, especialmente da região litorânea do município de Ipojuca, tem sido explorado de forma significativa poços artesanais como alternativa para suprir esse déficit. O aumento populacional e o fluxo de turistas na região têm trazido maior consumo de água, fazendo com que hotéis e pousadas façam uso de recursos hídricos subterrâneos através de perfuração de poços subterrâneos para suprir essa demanda. No entanto, é necessário assegurar o controle da qualidade das águas como forma de prevenir doenças de veiculação hídrica para a população residente e transitória nessas áreas de forte apelo turístico. 0 estudo se propõe caracterizar as águas de acordo com o padrão de potabilidade exigido pela legislação vigente e apresentar medidas que contribuam para melhorar a qualidade das águas dos poços estudados.

\section{REVISÃO TEÓRICA}

\section{Caracterização da Área de Estudo}

Os poços tubulares a serem estudados estão localizados em Hotéis na região costeira do município de Ipojuca, especificamente entre Cabo de Santo Agostinho e Porto de Galinhas Ipojuca/PE (figura 1). A escolha do local foi feita em função de Porto de Galinhas ser abastecido complementarmente por águas oriundas de poços tubulares.

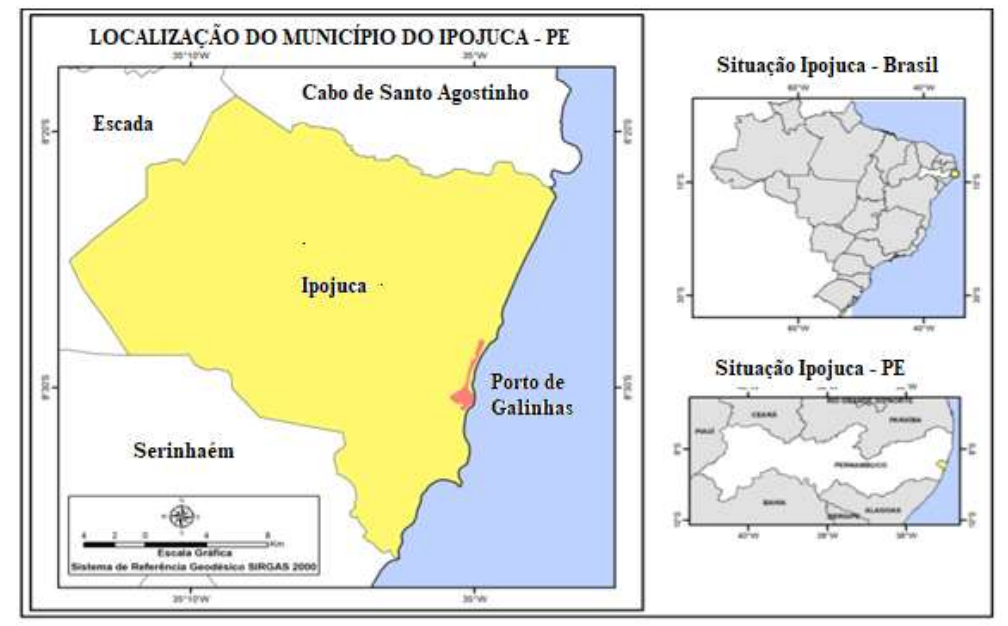

Figura 1: Mapa do Município de Ipojuca, Pernambuco. Fonte: ITEP (2017).

“O aquífero Cabo, objeto do presente estudo, encontra-se no Domínio da Planície do Recife, que inclui ainda os aquíferos Beberibe e Boa Viagem" (MONTENEGRO et al., 2000). Segundo Borba et al. (2010)

$O$ aquífero Cabo, se estende desde o município de Ipojuca ao sul até o lineamento Pernambuco, na altura do bairro do Pina, com direção aproximadamente $E-W$, com vigência para Nordeste nas proximidades da costa. Existe uma baixa permeabilidade do mesmo, devido à presença da argila e caulim na composição do cimento, bem como por 
intercalações de camadas ou lentes síltico-argilosas. Essa variação faciológica ocorre tanto na vertical como na horizontal, fazendo com que se apresente ora com maior permeabilidade, onde predomina a fáceis arenosa ora com menor permeabilidade, onde predomina a fácies síltico-argilosa. A recarga desse aquífero é caracterizada pela passagem de água por drenança vertical descendente do aquífero Boa Viagem de maneira muito lenta, uma vez que as camadas sílticoargilosas que ocorrem no aquífero superior possuem condutividade hidráulica muito baixa. A outra forma de recarga ocorre na planície do Recife no bairro do Barro, porém em área de apenas $5,5 \mathrm{~km}^{2}$.

A Figura 2 a seguir mostra a localização dos poços estudados.

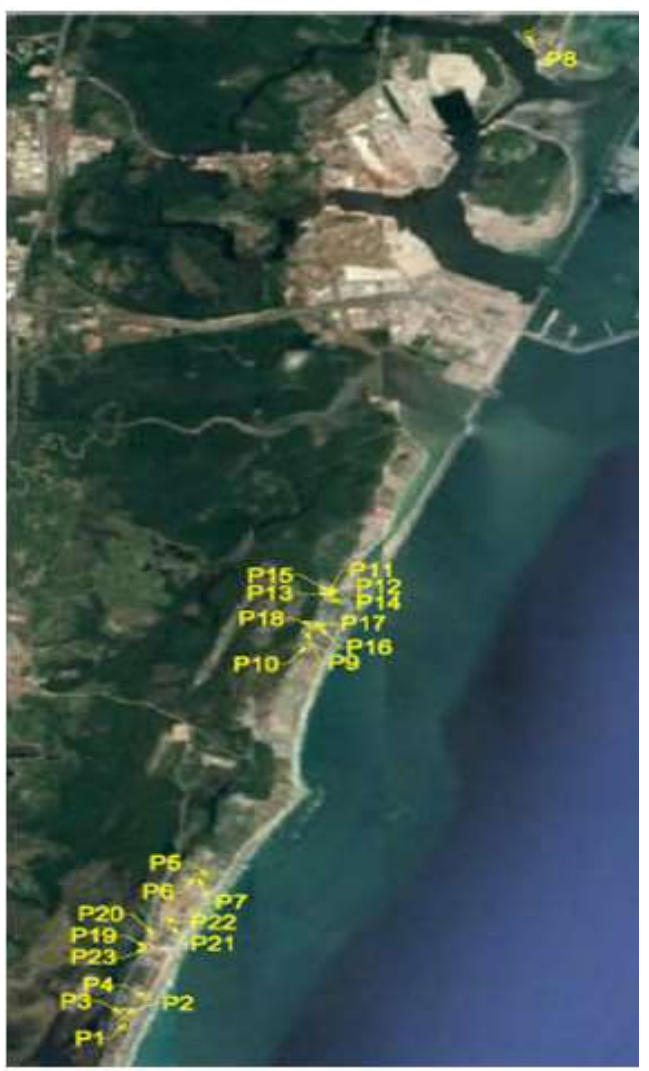

\begin{tabular}{|c|c|c|c|}
\hline Hotel & Poço correspondente & Latitude & Longitude \\
\hline H1 & P1 & $-8,48629$ & $-35,00138$ \\
\hline & P2 & $-8,48497$ & $-35,00111$ \\
\hline & P3 & $-8,48497$ & $-35,00166$ \\
\hline H2 & P4 & $-8,48288$ & $-34,99944$ \\
\hline H3 & P5 & $-8,46750$ & $-34,99305$ \\
\hline & P6 & $-8,46777$ & $-34,99444$ \\
\hline & P7 & $-8,46784$ & $-34,99402$ \\
\hline H4 & P8 & $-8,36111$ & $-34,96111$ \\
\hline H5 & P9 & $-8,43666$ & $-34,98333$ \\
\hline H6 & P10 & $-8,43861$ & $-34,98333$ \\
\hline H7 & P11 & $-8,43194$ & $-34,98111$ \\
\hline & P12 & $-8,43261$ & $-34,98098$ \\
\hline & P13 & $-8,43161$ & $-34,98107$ \\
\hline H8 & P14 & $-8,43611$ & $-34,98194$ \\
\hline & P15 & $-8,43583$ & $-34,98250$ \\
\hline & P16 & $-8,43583$ & $-34,98277$ \\
\hline H9 & P17 & $-8,47694$ & $-34,99817$ \\
\hline & P18 & $-8,47472$ & $-34,99786$ \\
\hline & P19 & $-8,47485$ & $-34,99716$ \\
\hline & P20 & $-8,47502$ & $-34,99844$ \\
\hline & P21 & $-8,47398$ & $-34,99660$ \\
\hline & P22 & $-8,47322$ & $-34,99737$ \\
\hline & P23 & $-8,47666$ & $-34,99916$ \\
\hline
\end{tabular}

Figura 2: Mapa de localização dos poços amostrados.

\section{MATERIAIS E MÉTODOS}

O estudo se desenvolveu a partir da coleta de dados secundários obtidos da APAC e CPRH no período de 2010 a 2018 referentes a 23 poços tubulares cadastrados que corresponderam a 30 amostras de água. Alguns hotéis possuem mais de um poço e para alguns deles existe mais de uma análise. Foram analisados os íons principais e os parâmetros físico-químicos: potencial hidrogeniônico $(\mathrm{pH})$, condutividade elétrica (CE), turbidez, dureza e sólidos totais dissolvidos (STD) e microbiológico: coliformes totais e fecais e bactérias heterotróficas. Para a identificação da adequação das águas para consumo humano foram avaliadas as amostras conforme o padrão de potabilidade estabelecido pela Portaria de Consolidação № 5 de setembro de 2017 (BRASIL, 2017).

Os dados hidroquímicos foram tabulados com o auxílio do programa Microsoft Excel e a partir da tabulação dos dados foi feita uma importação para o software livre Qualigraf (MÖBUS, 2014), empregado para o cálculo do balanço iônico e elaboração do diagrama de Piper para fins de caracterização hidroquímica da área de estudo. 
Os resultados das análises químicas foram submetidos a um balanço iônico entre cátions e ânions, como forma de verificação da confiabilidade das análises laboratoriais. Foi realizado o cálculo do erro prático (Ep\%) por meio do software Qualigraf utilizando duas técnicas. Uma considerando os valores da condutividade elétrica (CE) da água, e a outra os somatórios dos cátions ou ânions, sendo descartadas as amostras que não atendiam as duas técnicas.

Para a classificação iônica das águas subterrâneas utilizou-se o Diagrama de Piper, frequentemente usado para classificar o tipo químico da água de acordo com o conteúdo iônico dominante. O referido diagrama, também chamado de diagrama trilinear, posiciona do lado direito de um dos triângulos os valores das concentrações dos ânions $\left(\mathrm{HCO}_{3}{ }^{-}, \mathrm{Cl}^{-}, \mathrm{SO}_{4}{ }^{2-}\right)$ e no lado esquerdo os dos cátions $\left(\mathrm{Ca}^{2+}, \mathrm{Mg}^{2+}, \mathrm{Na}^{+}\right.$e K$\left.{ }^{+}\right)$. $\mathrm{O}$ cruzamento do prolongamento dos pontos na área do losango define sua posição e classifica a amostra de acordo com suas fácies hidroquímica (CAJAZEIRAS, 2007). Para construir o diagrama, as concentrações de cada íon expressos em mg/L são transformados em meq/L e, em seguida em percentagem do total de ânions e do total de cátions, separadamente (FEITOSA et al., 2000). As águas semelhantes são agrupadas e podem ser classificadas pela localização no diagrama.

A partir dos valores de íons das amostras analisadas foram estimadas algumas das razões iônicas mais amplamente utilizadas em estudos hidrogeoquímicos, que são bastante relevantes para este estudo, tais como as razões $\mathrm{rMg}^{2+} / \mathrm{rCa}^{2+}, \mathrm{rCa}^{2+} / \mathrm{rMg}^{2+}, \mathrm{rCa}^{2+} /\left(\mathrm{rHCO}_{3}{ }^{-}+\mathrm{rSO}_{4}{ }^{2-}\right), \mathrm{rK}^{+} / \mathrm{rNa}^{+}, \mathrm{rNa}^{+} / \mathrm{rCl}^{-}, \mathrm{rCl}^{-} / \mathrm{rHCO}_{3}{ }^{-}$e

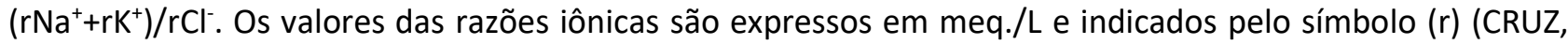
2006). Segundo Costa et al. (2008)

As razões iônicas, também designadas de índices hidrogeoquímicos, são relações existentes entre os íons dissolvidos na água e utilizadas para indicar; a possível relação do litotipo com a origem da água (marinha ou continental), a ação de fenômenos modificadores ou ainda indicar uma característica específica também designada de 'assinatura iônica' da água. Várias são as relações entre os íons (cátions ou aníons) que podem ser estabelecidas, sendo as mais usuais as seguintes: $\mathrm{rMg}^{2+} \mathrm{rCa}^{2+}, \mathrm{rK}^{+} / \mathrm{rNa}^{+}, \mathrm{rCl}^{-} / \mathrm{rHCO}_{3}^{-}$.

\section{RESULTADOS E DISCUSSÃO}

Considerando os erros do balanço iônico observados, foram descartadas 7 amostras que não atendem aos dois critérios utilizados no software QualiGraf (amostras 7, 9, 10, 14, 15,16, 17), restando da base de dados originais 23 amostras que correspondem a 17 poços. As propriedades física, química e biológica da água são usadas como parâmetros para saber se o corpo hídrico está no nível aceitável para o consumo humano. Foram reunidos os resultados das análises químicas das amostras estudadas na Tabela 1 e posteriormente comparados com o Valor Máximo Permitido (VMP) estabelecido pela Portaria de Consolidação № 5 do Ministério da Saúde (BRASIL, 2017).

$\mathrm{Na}$ área estudada, as amostras de águas subterrâneas possuem STD com concentração variando entre 301 e 1089 mg/L e valor médio de 633,16 mg/L. Segundo a classificação proposta pela resolução CONAMA N 357/2005 (BRASIL, 2005) essas amostras são classificadas como salobras, uma vez que 73,9\% apresentaram um valor de STD acima de 500 mg/L. Das 23 amostras de águas subterrâneas analisadas, 21 (91,3\%) encontram-se dentro do padrão aceitável, e as amostras 2 e 3 que correspondem ao poço 2 
apresentam valores superiores ao permitido pela Portaria de Consolidação № 5 (BRASIL, 2017).

Tabela 1: Resultados de STD, CE, pH, dureza e turbidez das amostras.

\begin{tabular}{|c|c|c|c|c|c|c|}
\hline Poço & Amostra & STD (mg/L) & CE $(\mu \mathrm{S} / \mathrm{cm})$ & pH & Dureza (mg/L) & Turbidez (UT) \\
\hline P1 & 1 & 923,00 & 1435,00 & 7,80 & 271,110 & 1,00 \\
\hline $\mathrm{P} 2$ & 2 & 1089,00 & 1806,00 & 6,40 & 281,00 & 0,19 \\
\hline $\mathrm{P} 2$ & 3 & 1048,00 & 1782,00 & 6,90 & 463,40 & 0,19 \\
\hline P3 & 4 & 801,00 & 1378,00 & 6,90 & 300,70 & 0,19 \\
\hline $\mathrm{P} 4$ & 5 & 388,00 & 587,00 & 7,40 & 187,30 & 0,19 \\
\hline P5 & 6 & 617,07 & 984,00 & 7,51 & 309,38 & 1,60 \\
\hline P7 & 8 & 387,55 & 618,00 & 6,85 & 199,98 & 2,40 \\
\hline P10 & 11 & 453,00 & 724,00 & 8,60 & 86,10 & 1,8 \\
\hline P11 & 12 & 620,00 & 1017,00 & 7,50 & 98,60 & 0,19 \\
\hline P11 & 13 & 611,00 & 1008,00 & 7,70 & 98,60 & 0,19 \\
\hline P15 & 18 & 546,00 & 838,70 & 7,50 & 113,40 & 0,19 \\
\hline P16 & 19 & 726,00 & 1196,00 & 7,60 & 147,90 & 0,19 \\
\hline P17 & 20 & 653,00 & 1025,00 & 7,10 & 212,00 & 0,19 \\
\hline P17 & 21 & 643,00 & 1394,00 & 6,30 & 276,00 & 0,19 \\
\hline P18 & 22 & 620,00 & 1046,00 & 6,60 & 187,30 & 0,19 \\
\hline P18 & 23 & 637,00 & 1395,00 & 8,00 & 207,10 & 0,70 \\
\hline P19 & 24 & 714,00 & 1134,00 & 7,00 & 251,40 & 0,19 \\
\hline P19 & 25 & 759,00 & 1625,00 & 6,70 & 285,90 & 0,30 \\
\hline P20 & 26 & 526,00 & 950,00 & 7,70 & 221,80 & 0,19 \\
\hline P21 & 27 & 772,00 & 1511,00 & 6,50 & 251,40 & 0,19 \\
\hline $\mathrm{P} 22$ & 28 & 301,00 & 1147,00 & 7,70 & 98,60 & 0,19 \\
\hline $\mathrm{P} 23$ & 29 & 364,00 & 489,60 & 7,00 & 182,40 & 8,20 \\
\hline P23 & 30 & 364,00 & 603,00 & 7,80 & 172,50 & 4,80 \\
\hline \multicolumn{2}{|c|}{ Média } & 633,16 & 1117,10 & 7,26 & 213,22 & 1,03 \\
\hline \multicolumn{2}{|c|}{ Mínimo } & 301,00 & 489,60 & 6,30 & 86,10 & 0,19 \\
\hline \multicolumn{2}{|c|}{ Máximo } & 1089,00 & 1806,00 & 8,60 & 463,40 & 8,20 \\
\hline \multicolumn{2}{|c|}{ VMP } & 1000,00 & & $6,00-9,50$ & 500,00 & 5 \\
\hline
\end{tabular}

$\mathrm{VMP}=$ valor máximo permitido.

Quanto à condutividade elétrica, os resultados variam de 489,6 a 1806,0 $\mu \mathrm{S} / \mathrm{cm}$. Seguindo o critério definido por Paiva (2003) e analisando a CE das 23 amostras relativas aos 17 poços, 3 poços com CE inferior a $700 \mu \mathrm{S} / \mathrm{cm}$ são considerados não salinizados (P4, P7 e P23), 11 poços com CE entre 700 e $1500 \mu \mathrm{S} / \mathrm{cm}$ apresentaram início de salinização (P1, P3, P5, P10, P11, P15, P16, P17, P18, P20 e P22) e 3 poços com CE entre 1500 e $2300 \mu \mathrm{S} / \mathrm{cm}$ foram considerados já salinizados (P2, P19 e P21). A amostra 24 do P19 coletada em jan/18 passou de início de salinização para salinização acentuada em jul/18 (amostra 25). Analisando os valores de pH das amostras de água da área em estudo observa-se uma variação entre 6,3 a 8,6 com o valor médio de 7,26, indicando tendência a alcalinização.

Com relação ao parâmetro dureza, as amostras em estudo para serem consideradas próprias para consumo humano, devem apresentar valor máximo de $500 \mathrm{mg} / \mathrm{L}$ de $\mathrm{CaCO}_{3}$. As amostras analisadas apresentaram valores entre 86,10 e $463,4 \mathrm{mg} / \mathrm{L}$ estando, portanto dentro do limite permitido pela Portaria de Consolidação № 5. Baseado na classificação de Custódio et al. (1983) para dureza, 4 amostras são consideradas moderadamente duras, 7 amostras duras e 12 amostras muito duras.

Para o parâmetro turbidez, que trata dos sólidos em suspensão na água, os valores das amostras variaram entre 0,19 e 8,20 uT, com 95,65\% das amostras atendendo ao padrão de potabilidade estabelecidos pela Portaria de Consolidação № 5 (BRASIL, 2017) e apenas a amostra 29 apresentando valor superior ao VMP de 5,0 UT este fato pode ter ocorrido devido a uma manutenção recente do poço. O resultado das 
análises microbiológicas das amostras de água pode ser visto na Tabela 2. Em vermelho temos os parâmetros das amostras em desconformidade com as exigências das normas vigentes.

Tabela 2: Resultados das análises microbiológicas das amostras de água.

\begin{tabular}{|l|l|l|l|l|}
\hline Poço & Amostra & Coliformes totais & Escherichia coli & Bactérias heterotróficas \\
\hline P1 & 1 & ausência & ausência & 3 \\
\hline P2 & 2 & $1,1 \times 10^{2}$ & ausência & 17 \\
\hline P2 & 3 & X & X & X \\
\hline P3 & 4 & ausência & ausência & ausência \\
\hline P4 & 5 & ausência & ausência & ausência \\
\hline P5 & 6 & ausência & ausência & ausência \\
\hline P7 & 8 & 4,6 & ausência & ausência \\
\hline P10 & 11 & ausência & ausência & $1,1 \times 10^{3}$ \\
\hline P11 & 12 & ausência & ausência & ausência \\
\hline P11 & 13 & ausência & ausência & ausência \\
\hline P15 & 18 & ausência & ausência & ausência \\
\hline P16 & 19 & ausência & ausência & ausência \\
\hline P17 & 20 & ausência & ausência & ausência \\
\hline P17 & 21 & ausência & ausência & 12 \\
\hline P18 & 22 & ausência & ausência & 3 \\
\hline P18 & 23 & ausência & ausência & 30 \\
\hline P19 & 24 & ausência & ausência & 32 \\
\hline P19 & 25 & ausência & ausência & 26 \\
\hline P20 & 26 & ausência & ausência & 5 \\
\hline P21 & 27 & ausência & ausência & 6 \\
\hline P22 & 28 & ausência & ausência & 81 \\
\hline P23 & 29 & ausência & ausência & 20 \\
\hline P23 & 30 & X & X & X \\
\hline VMP & AusênclA & AusENciA & Até 500 UFC/mL \\
\hline X & & \\
\hline
\end{tabular}

$\mathrm{X}=$ ausência do laudo para a análise microbiológica.

Dessas amostras 3 não estão em conformidade com a Portaria de Consolidação № 5 do Ministério da Saúde (amostras 2, 8 e 11), sendo recomendado a desinfecção dessas águas antes de serem usadas para consumo humano. Os métodos gráficos são ferramentas importantes para o entendimento do padrão hidroquímico das águas, sua relação com os aspectos litológicos existentes no aquífero e os processos hidroquímicos envolvidos na sua formação (GASTMANS et al., 2005). O diagrama de Piper gerado para as amostras pode ser visualizado na Figura 3.

Das 23 amostras analisadas, 52\% (12 amostras) foram classificadas como cloretadas sódicas, 17\% (4 amostras) como bicabornatada mista, 17\% (4 amostras) como cloretada mista, $9 \%$ (2 amostras) como bicabornatada sódica e 4\% (1 amostra) como sódica mista, indicando que o principal cátion dissolvido foi o sódio e o principal aníon o cloreto. Isso impacta na sua utilização para consumo humano, irrigação e indústria, indicando que em alguns poços se faz necessário tratamento de dessalinização após a captação das águas. Esta predominância de águas cloretadas sódicas pode estar relacionada às águas marinhas e à evaporação, que aumentam a concentração do cloreto nas águas subterrâneas, favorecida pela proximidade da área de pesquisa ao Oceano Atlântico, inserida na faixa costeira. Além do risco do avanço da cunha salina proveniente do mar, com o grande bombeamento de águas subterrâneas pelos poços vizinhos a pressão nos aquíferos vem diminuindo induzindo a recarga pelos corpos hídricos superiores com grande salinidade como: mangues, rios afluentes e canais. 


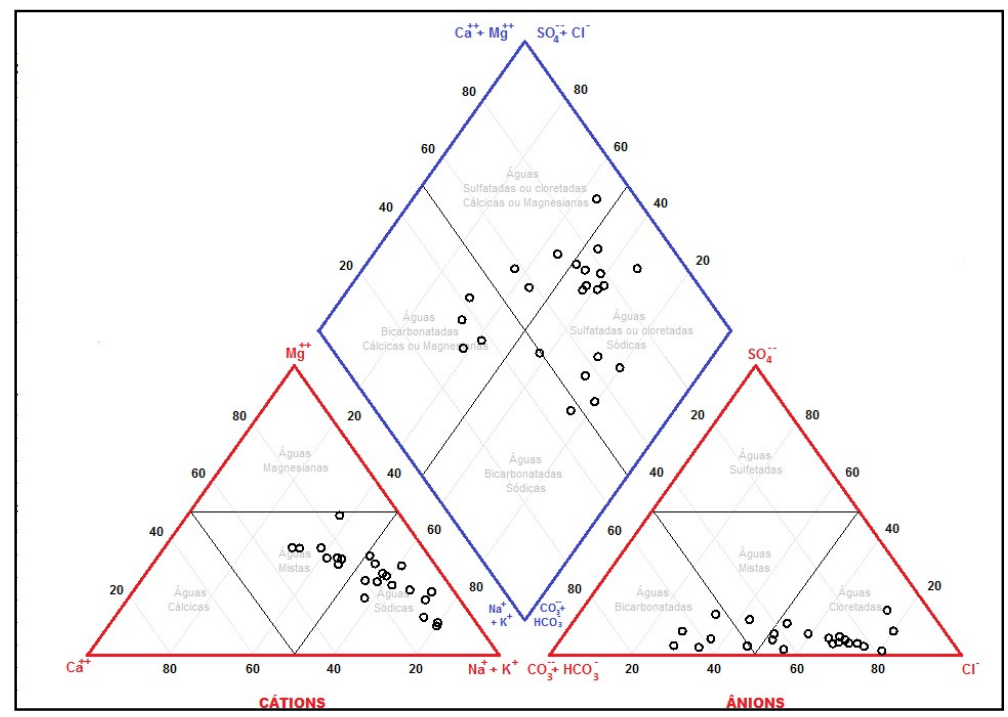

Figura 3: Diagrama de Pipper com a classificação das águas.

Para investigar se a causa da salinidade é de origem marinha, produzida pela intrusão, além das concentrações de alguns íons, algumas razões iônicas são utilizadas (MONTENEGRO et al., 2009). As razões iônicas $\mathrm{rCl}^{-} / \mathrm{rHCO}_{3}{ }^{-}, \mathrm{rMg}^{2+} / \mathrm{rCa}^{2+}, \mathrm{rCa}^{2+} / \mathrm{rMg}^{2+}, \mathrm{rK}^{+} / \mathrm{rNa}^{+},\left(\mathrm{rNa}^{+}+\mathrm{rK}^{+}\right) / \mathrm{rCl}^{-}, \mathrm{rNa}^{+} / \mathrm{rCl}^{-}$e $\mathrm{rCa}^{2+} /\left(\mathrm{rHCO}_{3}{ }^{-}+\mathrm{rSO}_{4}{ }^{2-}\right)$ foram escolhidas por reportarem possíveis indícios de intrusão marinha em aquíferos costeiros. Na Tabela 3 são apresentados os resultados de razões iônicas de interesse na análise de salinização por intrusão marinha.

Tabela 3: Resultado das razões iônicas para as amostras analisadas, em meq/L.

\begin{tabular}{|c|c|c|c|c|c|c|c|}
\hline Amostra & $\mathrm{rCl} / / \mathrm{rHCO}_{3}^{-}$ & $\mathrm{rMg}^{2+} / \mathrm{rCa}^{2+}$ & $\mathrm{rCa}^{2+} / \mathrm{rMg}^{2+}$ & $\mathrm{rK}^{+} / \mathrm{rNa}^{+}$ & $\mathrm{rNa}^{+}+\mathrm{rK}^{+/} \mathrm{rCl}^{-}$ & $\mathrm{rNa}^{+} / \mathrm{rCl}^{-}$ & $\mathrm{rCa}^{2+} / \mathrm{rHCO}_{3}{ }^{-}+\mathrm{rSO}_{4}{ }^{2-}$ \\
\hline 1 & 3,13 & 1,75 & 0,57 & 0,02 & 0,85 & 0,84 & 0,51 \\
\hline 2 & 6,49 & 2,16 & 0,46 & 0,03 & 0,85 & 0,82 & 0,51 \\
\hline 3 & 7,31 & 1,35 & 0,74 & 0,03 & 0,63 & 0,61 & 0,94 \\
\hline 4 & 4,33 & 2,21 & 0,45 & 0,02 & 0,70 & 0,69 & 0,75 \\
\hline 5 & 0,44 & 1,23 & 0,81 & 0,06 & 1,22 & 1,15 & 0,44 \\
\hline 6 & 1,32 & 3,29 & 0,30 & 0,05 & 0,76 & 0,72 & 0,38 \\
\hline 8 & 0,55 & 1,34 & 0,74 & 0,06 & 1,40 & 1,32 & 0,46 \\
\hline 11 & 0,69 & 1,13 & 0,89 & 0,04 & 2,26 & 2,17 & 0,19 \\
\hline 12 & 0,93 & 1,22 & 0,82 & 0,01 & 1,89 & 1,87 & 0,16 \\
\hline 13 & 1,76 & 1,00 & 1,00 & 0,02 & 1,35 & 1,32 & 0,25 \\
\hline 18 & 1,41 & 2,29 & 0,44 & 0,02 & 1,49 & 1,46 & 0,19 \\
\hline 19 & 1,19 & 4,00 & 0,25 & 0,01 & 1,47 & 1,46 & 0,12 \\
\hline 20 & 2,21 & 0,87 & 1,15 & 0,01 & 0,91 & 0,90 & 0,67 \\
\hline 21 & 2,28 & 1,54 & 0,65 & 0,01 & 0,69 & 0,68 & 0,67 \\
\hline 22 & 2,70 & 3,74 & 0,27 & 0,01 & 0,88 & 0,87 & 0,27 \\
\hline 23 & 3,39 & 2,00 & 0,50 & 0,01 & 0,83 & 0,82 & 0,58 \\
\hline 24 & 2,80 & 1,32 & 0,76 & 0,01 & 0,78 & 0,77 & 0,68 \\
\hline 25 & 2,55 & 2,40 & 0,42 & 0,01 & 0,77 & 0,76 & 0,44 \\
\hline 26 & 1,21 & 1,50 & 0,67 & 0,02 & 0,88 & 0,86 & 0,47 \\
\hline 27 & 2,47 & 1,99 & 0,50 & 0,01 & 0,85 & 0,84 & 0,45 \\
\hline 28 & 0,91 & 1,50 & 0,67 & 0,02 & 1,39 & 1,36 & 0,36 \\
\hline 29 & 0,62 & 1,18 & 0,85 & 0,01 & 0,87 & 0,86 & 0,51 \\
\hline 30 & 0,41 & 1,50 & 0,67 & 0,03 & 1,35 & 1,31 & 0,35 \\
\hline Média & 2,22 & 1,85 & 0,63 & 0,02 & 1,09 & 1,06 & 0,45 \\
\hline Mínimo & 0,41 & 0,87 & 0,25 & 0,01 & 0,63 & 0,61 & 0,12 \\
\hline Máximo & 7,31 & 4,00 & 1,15 & 0,06 & 2,26 & 2,17 & 0,94 \\
\hline
\end{tabular}

$\mathrm{O}$ índice $\mathrm{rCl}^{2} / \mathrm{rHCO}_{3}{ }^{-}$tem bastante utilidade na caracterização da intrusão salina, porque as águas continentais apresentam, normalmente, um valor entre 0,1 e 0,5 enquanto na água do mar o valor pode variar entre 20 e 50 (ALMEIDA, 2009). Uma razão $\mathrm{rCl}^{-} / \mathrm{rHCO}_{3}^{-}$maior que 1,8 indica água com salinização inicial 
e uma razão maior do que 6, água com salinização adiantada (ITABAIANA et al., 2018). As águas analisadas apresentam valores entre 0,41 a 7,31. Sendo que as amostras 1, 2 3, 4, 20, 21, 22, 23, 24, 25 e 27 apresentam valores correspondentes a indício de salinização.

A partir das determinações dos íons cálcio e magnésio foram obtidas as razões iônicas $\left(\mathrm{rMg}^{2+} / \mathrm{rCa}^{2+}\right)$ a fim de avaliar o possível efeito da intrusão da água do mar nas águas subterrâneas. $O$ índice compreendido entre 0,3 e 1,5 foi adotado como indicativo de águas doces e da ordem de 5 para água do mar (ALMEIDA, 2009). As amostras analisadas apresentaram média de 1,85 para esta razão, e apenas a amostra 19 se aproxima do valor que corresponde a água do mar.

Razões de $\mathrm{rCa}^{2+} / \mathrm{rMg}^{2+}$ e $\mathrm{rCa}^{2+} /\left(\mathrm{rHCO}_{3}{ }^{-}+\mathrm{rSO}_{4}{ }^{2-}\right)$ maiores que 1 são indicadoras da chegada da intrusão marinha. Para as amostras obtiveram-se valores médios de 0,63 e 0,45 respectivamente. Porém, as amostras 13 e 20 na 1a razão e a amostra 3 na 2a razão tem valor próximo de 1 indicando intrusão marinha (CABRAL et al., 2004). A relação $\mathrm{rK}^{+} / \mathrm{rNa}^{+}$apresenta um valor médio de 0,02 com valores entre 0,01 e 0,06 . Segundo Custódio et al. (1983) nas águas subterrâneas em geral a relação $\mathrm{rK}^{+} / \mathrm{rNa}^{+}$apresenta valores menores que 1 (em águas marinhas o índice $\mathrm{rK}^{+} / \mathrm{rNa}^{+}$varia entre 0,020 e 0,025 e em águas doces entre 0,004 e 0,28), devido principalmente a fixação de $\mathrm{K}^{+}$nos argilominerais. As amostras 1, 4, 13, 18 e 28 apresentam valores correspondentes a águas marinhas.

A razão dos íons alcalinos por cloreto $\left(\left(\mathrm{rNa}^{+}+\mathrm{rK}^{+}\right) / \mathrm{rCl}^{-}\right)$é muito útil nos estudos de salinização em áreas costeiras (CABRAL et al., 2004). A média encontrada desta razão para as amostras analisadas foi de 1,09 , valor acima do especificado para a água do mar que varia entre 0,87 e 0,89. Considerando esta razão, as amostras 22, 26 e 29 apresentam características de água do mar e as amostras 1, 3 e 27 apresentam valores bem próximos.

Para a água do mar a razão $\mathrm{rNa}^{+} / \mathrm{rCl}^{-}$é de aproximadamente 0,86 . O valor para a água doce é uma função do processo químico durante a recarga, mas geralmente é $1,0 \pm 0,1$. Quando a água salina desloca a água doce a razão alcalinos/cloreto diminui com relação aos valores da água doce e frequentemente alcançam valores mais baixos que águas marinhas (CABRAL et al., 2004). Para as amostras a razão $\mathrm{rNa}+\mathrm{rCl}-$ apresenta um valor médio de 1,06 com valores entre 0,61 e 2,17. Considerando essa razão as amostras 1, 2, $3,4,6,21,23,24,25,26,27$ e 29 apresentam indícios de intrusão marinha.

Apesar de estudos anteriores realizados no aquífero Cabo (COSTA et al., 2008; MONTENEGRO et al., 2001) terem apontado que a contaminação salina em alguns poços é decorrente da má construção dos mesmos, que serviriam de conduto hidráulico entre os aquíferos Boa Viagem (superior) e Cabo (inferior), a influência marinha não deve ser descartada (MONTENEGRO et al., 2009).

Alguns dados das razões iônicas obtidas no presente estudo não se encontram nas faixas de variação características das águas continentais indicando a possibilidade de intrusão salina (água do mar). Apesar desses resultados, a salinização pode ter outras causas como: fenômenos de drenança vertical de domínios subterrâneos, rios salinizados e presença de mangues. Consequentemente, estudos mais detalhados necessitam ser realizados para identificar as causas da salinização. 


\section{Ações que podem contribuir para melhorar a qualidade das águas dos poços utilizados na área estudada}

Segundo Hirata et al. (2016), as águas subterrâneas não recebem a devida atenção por parte dos órgãos gestores, pois a sociedade subestima a importância desse recurso. Dado o grande potencial dos aquíferos para fornecer ainda mais água, é necessário que o Estado assuma uma postura de parceiro dos usuários, orientando-os e implementando ações de proteção, incluindo: a) Esclarecimento da importância das águas subterrâneas para o abastecimento público e privado, bem como para o ambiente e o bem estar social; b) Instituição de um programa de comunicação social que vise estimular a regularização dos poços e conscientize os usuários público e privado sobre as boas práticas para o uso correto da água subterrânea; c) Exigência de que as normas da ABNT, para construção de poços tubulares, sejam cumpridas e de que os pedidos de autorização, para perfuração de novos poços, sejam precedidos de estudos sobre riscos de contaminação e de superexploracao do aquífero; d) Orientação dos usuários, através de canais de serviço ao usuário, com relação ao auto monitoramento da água dos seus poços, a fornecer dados sobre a operação do poço de forma sistemática, e a comunicar eventuais problemas aos órgãos competentes; e) Capacitação dos órgãos governamentais para orientar, gerenciar e fiscalizar o uso dos recursos hídricos subterrâneos. f) Compatibilização do planejamento territorial com a disponibilidade dos recursos hídricos subterrâneos, fazendo com que este recurso seja tratado de forma correta nos planos de governo e das bacias hidrográficas.

Além das ações supracitadas é importante que os órgãos gestores estejam atentos para os riscos de exaustão e de salinização que vêm caracterizando a sobre-explotação desse manancial hídrico, estabelecendo restrições nas vazões máximas a serem captadas por poços na área de ocorrência do aquífero. A necessidade de uma gestão otimizada das águas subterrânea será facilitada pela modernização, com o desenvolvimento de um sistema de banco de dados integrado contendo informações geográficas, litológicas, microbiológicas, físico-químicas, hidrodinâmicas de cada poço para que possam ser feitas comparações da evolução do uso das águas do aquífero com um comportamento temporal das mesmas levando agilidade aos órgãos governamentais na orientação de uso, monitoramento, liberação de licenças ambientais e explotação.

\section{CONCLUSÕES}

A seguir são elencadas as principais conclusões do presente trabalho: a) Em relação à avaliação microbiológica as amostras em sua maioria $(85,7 \%)$ não apresentam contaminação atendendo aos padrões de potabilidade definidos pela Portaria de Consolidação no 5 de 28/09/2017; b) Quanto à qualidade físicoquímica da água, as amostras em sua maioria (73,9\%) são salobras apresentam uma grande quantidade de sólidos dissolvidos e um alto valor de condutividade elétrica. Em uma amostra a turbidez está em desconformidade com a legislação vigente, provavelmente por ter havido manutenção recente no poço. Com relação ao parâmetro dureza, as amostras em estudo são consideradas próprias para consumo humano. Os valores de $\mathrm{pH}$ em todas as amostras coletadas situam-se na faixa permitida pela legislação. Onde se conclui que a maioria das amostras analisadas atende aos padrões de potabilidade; c) Os resultados apresentados 
nos Diagrama de Piper indicam a predominância (52\%) de águas cloretadas sódicas; d) Alguns resultados das razões iônicas obtidas no presente estudo não se encontram nas faixas de variação características das águas continentais indicando a possibilidade de intrusão salina (água do mar). Apesar desses resultados, a salinização pode ter outras causas como: fenômenos de drenança vertical de domínios subterrâneos, rios salinizados e presença de mangues. Consequentemente, estudos mais detalhados necessitam ser realizados para identificar as causas da salinização.

\section{REFERÊNCIAS}

ALMEIDA, G. M.. Estudo do Aquífero Costeiro de Maricá/RJ: Instrumentação e Investigação do Comportamento da Cunha Salina. Dissertação (Mestrado em Geologia) - Universidade Federal do Rio de Janeiro, Rio de Janeiro, 2009.

BORBA, A. L. S.; COSTA FILHO, W. D.; MASCARENHAS, J. C.. Configuração geométrica dos Aquíferos da Região Metropolitana do Recife. In: CONGRESSO BRASILEIRO DE ÁGUAS SUBTERRÂNEAS, 16; ENCONTRO NACIONAL DE PERFURADORES DE POÇOS, 17. Anais. São Luís, 2010. p.1-14.

BRASIL. Resolução CONAMA no 357, de 17 de março de 2005. Classificação de águas, doces, salobras e salinas do Território Nacional. Brasília: DOU, 2005.

BRASIL. Portaria de Consolidação $n=5$ de 28 de setembro de 2017. ANEXO XX. Do controle e da vigilância da qualidade da água para consumo humano e seu padrão de potabilidade. Brasília: DOU, 2017.

CABRAL, J. J. S. P.; PAIVA, A. L. R.. Água subterrânea: Aquíferos Costeiros e Aluviões, Vulnerabilidade e Aproveitamento. Recife: UFPE, 2004.

CAJAZEIRAS, C. C. A.. Qualidade e Uso das Águas Subterrâneas e a Relação com Doenças de Veiculação Hídrica, Região de Crajubar/CE. Dissertação (Mestrado em Geologia) - Universidade Federal do Ceará, Fortaleza, 2007.

COSTA, W. D.; SANTOS, M. A. V.; COSTA FILHO, W. D.. Causas de salinização da água dos poços em áreas do Recife. In: CONGRESSO BRASILEIRO DE ÁGUAS SUBTERRÂNEAS, 15. Anais, 2008.

CRUZ, A.. Estudo de processos de salinização de aquíferos no litoral leste do estado do Rio de Janeiro: modelagem hidrogeoquímica e avaliação de vulnerabilidade à intrusão marinha. Dissertação (Mestrado em Geologia) -

Universidade Federal do Rio de Janeiro, Rio de Janeiro, 2006

CUSTÓDIO, E.; LLAMAS, M. R.. Hidrologia Subterrânea. 2 ed. Barcelona: Omega S.A., 1983.

FEITOSA, F. A. C.; MANOEL FILHO, J.. Hidrogeologia: Conceitos e Aplicações. 2 ed. Fortaleza: CPRM, 2000.

GASTMANS, D.; ALBERTO, M. C.; BUFON, A. G. M.; MORAES, F. T.; SANTOS, M. M.; SILVA, J. R. M.; CHANG, H. K.. Implicações hidroquímicas da interação rocha-água: interpretações através da representação gráfica de análises químicas de águas subterrâneas. In: ENCONTRO NACIONAL DE PERFURADORES DE POÇOS, 14.; SIMPÓSIO DE HIDROGEOLOGIA DO SUDESTE, 2. Anais. Ribeirão Preto: ABAS, 2005.

HIRATA, R.; FERNANDES, A. J.; BERTOLO, R.. As águas subterrâneas: longe dos olhos, longe do coração e das ações para sua proteção. Acta Paulista de Enfermagem, v.29, n.6, p.3-5, 2016.

ITABAIANA, I. M.; TUBBS FILHO, D.; TEIXEIRA, P. A.. Análise das relações iônicas como parte da análise hidroquímica das águas subterrâneas à oeste do rio guandu - baixada Fluminense/RJ. In: CONGRESSO BRASILEIRO DE GEOLOGIA DE ENGENHARIA E AMBIENTAL, 16. Anais. São Paulo, 2018.

ITEP. Instituto Técnico-Científico de Perícia. Gestão Territorial Sustentável. ITEP, 2017.

MÖBUS, G.. Qualigraf Software para interpretação de análises físico-químicas. Versão 1.17. Fortaleza: FUNCEME, 2014.

MONTENEGRO, S. M. G. L.; MONTENEGRO, A. A.; LIMA, E. S.; DEMÉTRIO, J. G. A.; CABRAL, J. J. S. P.; MANOEL FILHO, J.; GOMES, S. V.; BARBALHO JR., C. G. P.; LAFAYETTE, K. P.. Dinâmica e evolução da salinização no aquífero Cabo, planície do Recife (PE). In: JOINT WORLD CONGRESS ON GROUNDWATER, 1. Anais. 2000.

MONTENEGRO, S. M. G.; CABRAL, J. J. S. P.; PAIVA, A. L. R. MONTENEGRO, A. A. A.; DEMETRIO, J. G. A.; CAVALCANTI, G. L.. Águas subterrâneas na zona costeira da planície do Recife (PE): evolução da salinização e perspectivas de gerenciamento. Revista Brasileira de Recursos Hídricos, v.14, n.3, p.81-93, 2009.

MONTENEGRO, S. M. G. L.; MONTENEGRO, A. A. A.; CABRAL, J. J. S. P.; DEMETRIO, J. G. A.; MANOEL FILHO, J.; LIMA, E. S.; OLIVEIRA, E. M.; PAIVA, A.. Monitoramento da salinidade no aquífero Cabo, na região costeira da Planície do Recife (PE). In: SIMP. HIDROG. NORDESE, 4. Anais. 2001, p.477-485.

PAIVA, A. L. R.. Problemas de salinização nos aquíferos costeiros da região central da cidade de Recife. In: CONGRESSO DO QUATERNÁRIO DOS PAÍSES DE LÍNGUA IBÉRICAS, 2. Anais. 2003.

A CBPC - Companhia Brasileira de Produção Científica (CNPJ: 11.221.422/0001-03) detém os direitos materiais desta publicação. Os direitos referem-se à publicação do trabalho em qualquer parte do mundo, incluindo os direitos às renovações, expansões e disseminações da contribuição, bem como outros direitos subsidiários. Todos os trabalhos publicados eletronicamente poderão posteriormente ser publicados em coletâneas impressas sob coordenação da Sustenere Publishing, da Companhia Brasileira de Produção Científica e seus parceiros autorizados. Os (as) autores (as) preservam os direitos autorais, mas não têm permissão para a publicação da contribuição em outro meio, impresso ou digital, em português ou em tradução. 